\title{
The effect of mirror therapy on the management of phantom limb pain
}

\author{
Fantom ekstremite ağrısının yönetiminde ayna terapisinin etkisi
}

\author{
Meltem YILDIRIM, ${ }^{1}$ Nevin KANAN ${ }^{2}$
}

\begin{abstract}
Summary
Objectives: In the last two decades, mirror therapy has become a frequently used method of managing phantom limb pain (PLP). However, the role of nurses in mirror therapy has not yet been well defined. This study examined the effect of mirror therapy on the management of PLP, and discusses the importance of mirror therapy in the nursing care of amputee patients. Methods: This quasi-experimental study was conducted in the pain management department of a university hospital and a prosthesis clinic in İstanbul, Turkey, with 15 amputee patients who had PLP. Forty minutes of practical mirror therapy training was given to the patients and they were asked to practice at home for 4 weeks. Patients were asked to record the severity of their PLP before and after the therapy each day using 0-10 Numeric Pain Intensity Scale.

Results: Mirror therapy practiced for 4 weeks provided a significant decrease in severity of PLP. There was no significant relationship between the effect of mirror therapy and demographic, amputation or PLP-related characteristics. Patients who were not using prosthesis had greater benefit from mirror therapy.

Conclusion: Mirror therapy can be used as an adjunct to medical and surgical treatment of PLP. It is a method that patients can practice independently, enhancing self-control over phantom pain. As mirror therapy is a safe, economical, and easy-to-use treatment method, it should be considered in the nursing care plan for patients with PLP.
\end{abstract}

Keywords: Mirror therapy; nursing care; pain management; phantom limb pain.

\section{Özet}

Amaç: Son iki dekatta, ayna terapisi fantom ekstremite ağrısının (FEA) yönetiminde sıkça kullanılmaya başlanan bir yöntemdir. Ancak, literatürde ayna terapisinde hemşirenin rolüne ilişkin yeterince bulgu yoktur. Bu çalışma, FEA üzerinde ayna terapisinin etkisini incelemek ve ampüte hastalara verilen hemşirelik bakımında ayna terapisinin kullanımının önemini vurgulamak amacıyla gerçekleştirildi.

Gereç ve Yöntem: Yarı deneysel düzendeki bu çalışma FEA bildiren 15 ampüte hasta ile İstanbul'daki bir üniversite hastanesi ve özel bir protez kliniğinde gerçekleştirildi. Verilen 40 dakikalık ayna terapisi eğitiminden sonra hastalardan dört hafta boyunca terapiye evde devam etmeleri ve 0-10 Sayısal Ağrı Şiddeti Skalası kullanarak günlük FEA puanlarını terapiden önce ve sonra kaydetmeleri istendi.

Bulgular: Dört hafta boyunca her gün uygulanan ayna terapisi ile FEA şiddetinde anlamlı bir düşüşün olduğu saptandı. Ayna terapisi uygulaması ile hastaların demografik özellikleri, ampütasyon ve/veya FEA ile ilişkili özellikleri arasında anlamlı bir ilişki görülmedi. Protez kullanmayan hastaların ayna terapisinden daha fazla yarar gördüğü saptandı.

Sonuç: Ayna terapisi FEA'nın tıbbi ve cerrahi tedavisine ek olarak destekleyici bir yöntem olarak uygulanabilir. Bu yöntem, aynı zamanda hastanın bağımsız olarak uygulayabileceği bir yöntem olması nedeniyle hastaların ağrı yönetimindeki özkontrollerini de artıracaktır. Bu bağlamda ayna terapisinin güvenli, ekonomik ve kullanımı kolay bir yöntem olması nedeniyle, FEA'sı olan hastaların hemşirelik bakım planına dahil edilmesi önemlidir.

Anahtar sözcükler: Ayna terapisi; hemşirelik bakımı; ağrı yönetimi; fantom ekstremite ağrısı.

\footnotetext{
'Department of Nursing, Yeditepe University Faculty of Health Sciences, İstanbul, Turkey 2Department of Nursing, İstanbul University, Florence Nightingale Faculty of Nursing, İstanbul, Turkey

Submitted: 10.08.2015 Accepted after revision: 19.01.2016 Available online date: 18.07.2016

Correspondence: Dr. Meltem Yıldıım. Yeditepe Üniversitesi, İnönü Mah., Kayıı̧dağı Cad., 34755, İstanbul, Turkey. Tel: +90 - 216- 5780000 e-mail: meltemyildirim9@gmail.com

C) 2016 Turkish Society of Algology
} 


\section{Introduction}

Phantom limb pain (PLP) is defined as painful sensations perceived in the missing part of an amputated limb. ${ }^{[1-4]}$ PLP is one of the main causes of disability and distress among amputees, ${ }^{[5]}$ and incidence of this phenomenon is up to 80 percent. ${ }^{[4,6-9]}$ Individual physiological, environmental, and psychological factors are involved in the etiology of PLP. ${ }^{[4,10-15]}$

Pathophysiology of PLP is not clearly known yet. However, it is speculated that central and peripheral nerve systems play an important role in the occurrence of PLP. ${ }^{[16-18]}$ The leading theory to explain pathophysiology of PLP is cortical reorganization. Neuroimaging studies have shown that somatosensory and motor cortex are malleable and develop an adaptation after certain incidents such as injuries or environmental challenges. According to cortical reorganization theory, there are neuroplastic changes in the cortical map after the amputation of the limb, and these changes might be related to PLP. ${ }^{[1,3,14,18]}$

Clinical characteristics of PLP differ from patient to patient; however, the most commonly reported characteristics are burning, stabbing, tingling, a sensation of being pinned down, cramps, itching, pressure, burning, electric shock-like feeling, heat or cold, and throbbing. ${ }^{[3,4,11,12,17,19,20]}$ The feeling of a phantom limb can be so vivid that the patient may attempt to stand up and walk, ${ }^{[12]}$ or sometimes it may feel like a paralyzed limb. ${ }^{[21,22]}$

Today, various methods are used in treatment of PLP, such as use of analgesics, anticonvulsants, antidepressants, muscle relaxants, anesthetic substances, and transcutaneous electrical nerve stimulation. Cognitive behavioral techniques, hypnosis, and acupuncture are other alternative methods that can be used in the treatment of PLP. However, none of these methods is sufficient alone, and certain treatment combinations may help to decrease the severity of PLP. ${ }^{[3,4,12,23]}$

An inspiring method in the treatment of PLP called mirror therapy was first presented by Vilayanur Ramachandran. ${ }^{[24,25]}$ The results of his first study with mirror therapy encouraged many scientists to conduct new studies on this therapy method. ${ }^{[13,14,26-30]}$

Since mirror therapy is a method that can be taught and practiced easily and independently, it should have a place in the nursing care plan of patients with PLP. However, there is currently no study in the literature related to the role of nurses in using mirror therapy for management of PLP. Therefore, the present study investigated the effect of mirror therapy on the management of PLP and discusses the results from the perspective of clinical practice and nursing care.

\section{Material and Methods}

\section{Design, date and setting}

This quasi-experimental study was conducted in the pain management department of a public university hospital and a private prosthesis clinic in İstanbul, Turkey, between September 21, 2011 and March 7, 2014.

\section{Inclusion criteria}

The inclusion criteria to participate in the study were being over the age of 18 , having unilateral upper or lower extremity amputation and having PLP, not having visual impairment or severe hearing loss, being able to read and write Turkish, not having any condition that prevents movement of opposite extremity (such as plaster cast, paralysis in the intact limb), not being diagnosed with a mental disorder that could diminish ability to concentrate during therapy, and having a calm environment at home/ hospital to practice mirror therapy.

\section{Participants}

The study started with 24 patients who had PLP. Following explanation of the goals and concept of the study, 2 patients decided not to participate. Mirror therapy was taught to 22 patients who agreed to participate in the study and gave written informed consent. Six of the 22 patients stopped practicing mirror therapy during the data collection process and these patients were dropped from the statistical analysis due to lack of data. One patient was excluded because of a diagnosis of major depression during the study period. The research was concluded with 15 patients who were able to practice mirror therapy every day for 4 weeks and complete the daily Mirror Therapy Practice Follow-Up Booklet.

\section{Data collection}

Patient Information Form: The form was created by researchers in accordance with the literature and 
consisted of 3 sections and 18 questions related to demographic characteristics, amputation, and PLPrelated features.

Mirror Therapy Practice Follow-Up Booklet: This booklet consisted of 28 pages of daily follow-up to document daily PLP scores before and after the mirror therapy and the duration of therapy practice. $\mathrm{Nu}$ meric Pain Intensity Scale from 0 to 10 was used to record pain score.

\section{Procedure}

Explanation and data collection: The goals and concept of the study were explained to the patients, and those who agreed to participate signed an informed consent form. Each patient was given an unbreakable acrylic mirror that had been pre-cut and pre-

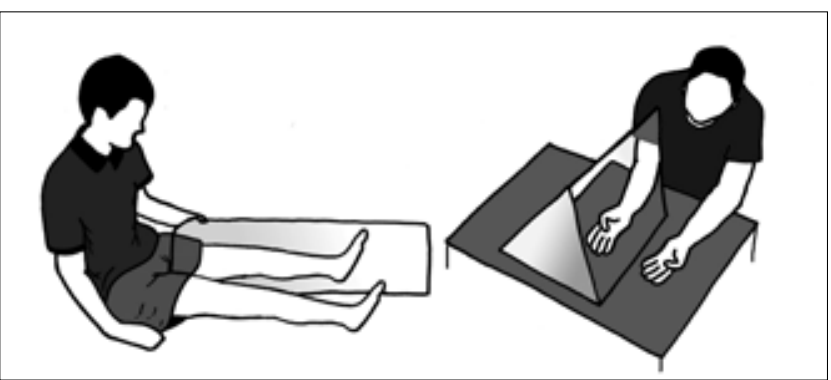

Figure 1. Appearance and position of the mirror for lower and upper limb amputees.

pared (Figure 1) for upper/lower extremity. Patients were then asked for demographic, amputation, and PLP details.

Teaching mirror therapy: The mirror therapy practical training took approximately 40 minutes. The steps followed during the training session can be

Table 1. Steps of practical education for mirror therapy

\begin{tabular}{ll}
\hline Duration & Steps of the education \\
\hline$\sim 5 \mathrm{~min}$ & 1. Preparation of the environment for mirror therapy \\
- & Minimize external stimulants (television, noise etc.) as much as possible. \\
- If the patient agrees, ask for the collaboration of a relative who can support the patient physically \\
and emotionally. \\
- - Ask the patient to take off all accessories on the intact limb (ring, bracelet, watch, sock etc.) \\
- Ensure that the patient is in a comfortable position. \\
2. Explanation of the objective and expected benefits of mirror therapy \\
- Give simple but enough information about the objective and working mechanism of mirror \\
therapy. \\
- Explain the expected benefits of mirror therapy. \\
- Encourage the patient to ask questions and answer all questions carefully. \\
3. Practical teaching of mirror therapy \\
- Evaluate the severity of current phantom limb pain with 0 to 10 Numeric Pain Intensity Scale. \\
- Explain the basic rules that the patient needs to follow during mirror therapy: \\
- Eyes should always be focused on the reflection in the mirror. \\
- Both limbs (intact and phantom limb) should do symetrical movements: moving the \\
extremity forward and back, rotating the wrist/ankle joint, moving the fingers, and opening and \\
\\
closing the hand, for upper extremity amputees. The patient is free to decide which movement \\
he/she will repeat in front of the mirror, and how long he/she will continue with 1 movement. \\
If the patient feels comfortable repeating only 1 movement, this is also acceptable. \\
- Mirror therapy should be practiced every day, at least once a day. It should be underlined that \\
contuniuation of the therapy is very important to achieve expected benefits. There is no \\
maximum number of repetitions per day. \\
- Preferably, 1 session of mirror therapy should last minimum of 20 minutes. \\
- Watch the patients for $5-10$ minutes and evaluate application of these rules carefully. \\
4. Ending mirror therapy \\
- Evaluate the severity of current phantom limb pain with 0 to 10 Numeric Pain Intensity Scale. \\
- Answer any questions of the patient and relative. \\
- End the training process when patient is capable of practicing mirror therapy alone. \\
$\sim 5$ min
\end{tabular}


Table 2. Distribution of patient PLP-related characteristics $(n=15)$

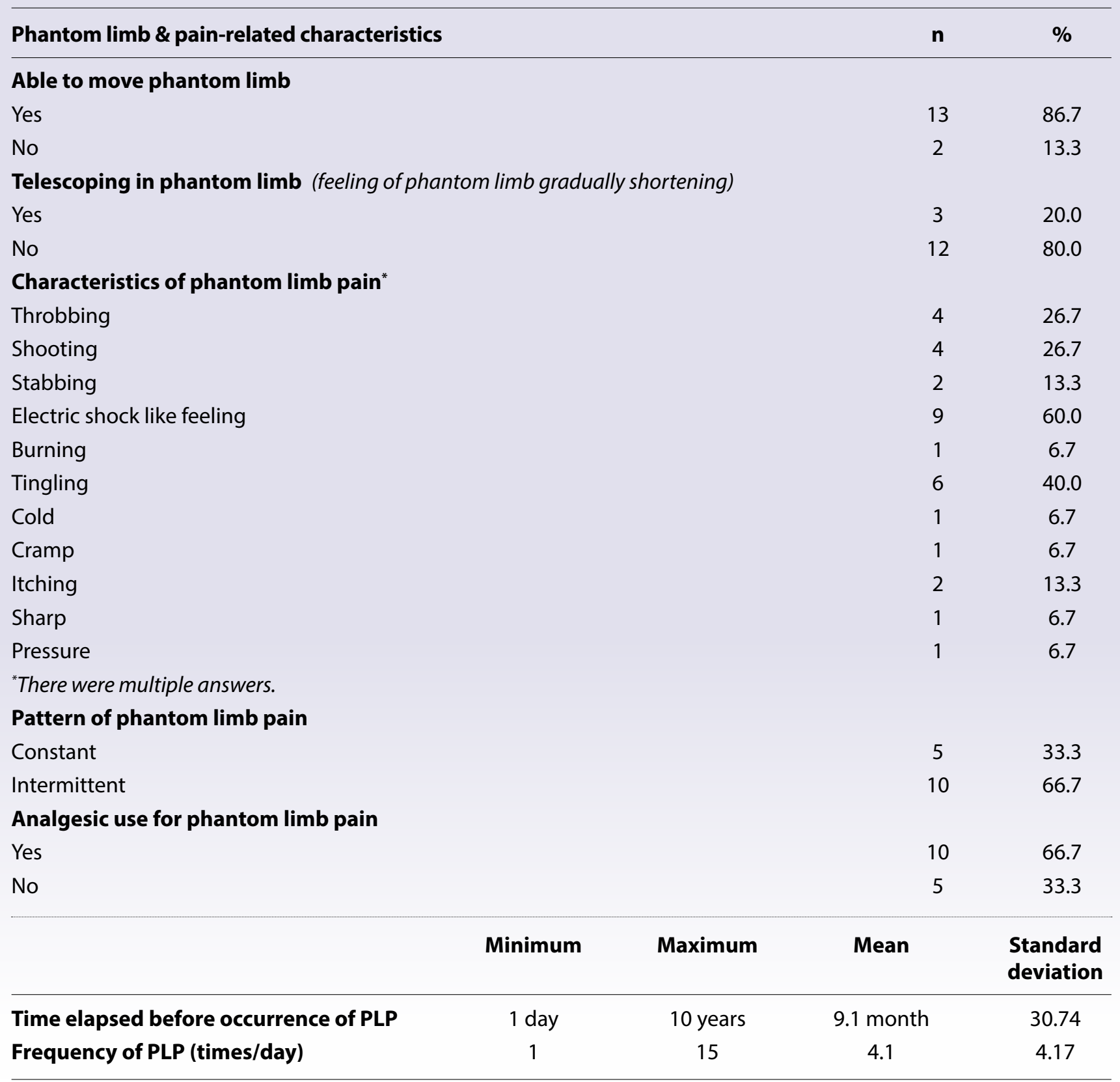

seen in Table 1.

Continuation of mirror therapy practice: When the researcher was convinced that the patient was capable of continuing mirror therapy alone correctly, patients took the mirror and the Mirror Therapy Practice Follow-Up Booklet home to continue the therapy. Patients were called by phone 2 times a week to encourage them and to answer any questions. After the 4-week practice period, the Mirror Therapy Practice Follow-Up Booklet was collected and they were told to keep the mirror if they wanted to continue practicing mirror therapy.

\section{Statistical evaluation}

Statistical analysis was performed using SPSS software (version 21.0; SPSS Inc., Chicago, IL, USA). Data were evaluated for homogeneity with One Sample Kolmogorov-Smirnov Test and a homogeneous distribution was found. However, as the sample size $(n=15)$ was less than 30 , non-parametric tests were used for statistical analysis. Descriptive statistics, Friedman test, Wilcoxon signed-rank test, MannWhitney $U$ test, Spearman's correlation analysis, and linear regression analysis were used. 


\section{Ethical aspect of the study}

The study was conducted in accordance with the World Medical Association (WMA) Declaration of Helsinki (DoH). Ethical committee approval was obtained before the start of the study and written permission was obtained from the public university hospital and private prosthesis center. In addition, patients were asked if they wanted to participate in the study, and those who accepted gave written informed consent. A copy of the signed consent form was also given to patients.

\section{Results}

Of the total participants, $86.7 \%(n=13)$ were male, $40 \%(n=6)$ were educated to elementary school level and average age was $52.13 \pm 16.68$ years.

Peripheral vascular disease (PVD) was the reason for amputation in $46.6 \%(n=7)$ of the patients in the present study, and $86.7 \%(n=13)$ were lower limb amputees. A majority, $80 \%(n=12)$, of the patients stated that they had experienced pain in the limb before amputation, and $58.3 \%(n=7)$ stated that the pain continued.

As seen in Table $2 ; 86.7 \%(n=13)$ of patients stated that they could move the phantom limb and $20 \%$ $(n=3)$ had experienced telescoping. Electric shocklike feeling was the most commonly reported type of PLP at $60 \%(n=9)$, followed by tingling sensation at $40 \%(n=6)$. More than half of the patients, $66.7 \%$ $(n=10)$, stated that their PLP was intermittent, and $66.7 \%(n=10)$ were using analgesics for the pain.

There was a statistically significant decrease in average PLP scores every week of the study period and for 1 -month total score $(p<0.01)$ (Table 3$)$.

It was found that patients who weren't using prosthe-

Table 3. Distribution of average PLP score difference before and after mirror therapy at each week and 1 Month $(n=15)$

\begin{tabular}{|c|c|c|c|c|c|c|c|c|}
\hline & \multicolumn{3}{|c|}{$\begin{array}{l}\text { Average PLP Score } \\
\text { before mirror therapy }\end{array}$} & \multicolumn{3}{|c|}{$\begin{array}{l}\text { Average PLP Score } \\
\text { after mirror therapy }\end{array}$} & \multirow{2}{*}{$\mathbf{Z}$} & \multirow{2}{*}{$\mathbf{p}$} \\
\hline & $\mathbf{n}$ & Mean & $\begin{array}{l}\text { Standard } \\
\text { deviation }\end{array}$ & $\mathbf{n}$ & Mean & $\begin{array}{l}\text { Standard } \\
\text { deviation }\end{array}$ & & \\
\hline $1^{\text {st }}$ week & 15 & 5.09 & 1.77 & 15 & 3.49 & 1.59 & -3.124 & $0.002^{*}$ \\
\hline $2^{\text {nd }}$ week & 15 & 4.29 & 1.36 & 15 & 2.31 & 1.31 & -3.295 & $0.001^{*}$ \\
\hline $3^{\text {rd }}$ week & 15 & 3.98 & 1.35 & 15 & 1.93 & 1.10 & -3.239 & $0.001^{*}$ \\
\hline $4^{\text {th }}$ week & 15 & 3.23 & 1.75 & 15 & 1.46 & 1.18 & -3.211 & $0.001^{*}$ \\
\hline 1 month total & 15 & 4.15 & 1.21 & 15 & 2.30 & 0.98 & -3.296 & $0.001^{*}$ \\
\hline
\end{tabular}

${ }^{*} \mathrm{p}<0.01 ; \mathrm{Z}=$ Wilcoxon Signed Ranks Test.

Table 4. Effect of prosthesis use on average PLP score difference before and after mirror therapy at the end of 1 Month $(n=15)$

\begin{tabular}{lccccc}
\hline Prosthesis usage & $\mathbf{n}$ & Mean & Standard deviation & $\mathbf{Z}$ & $\mathbf{p}$ \\
\hline Yes & 5 & 0.91 & 1.29 & -2.393 & $0.013^{*}$ \\
No & 10 & 2.31 & 0.75 & & \\
\hline
\end{tabular}

Z=Mann-Whitney U Test

Regression analysis to determining effect of prosthesis on success of mirror therapy

\begin{tabular}{lcccccc}
\hline B & Standard deviation & $\boldsymbol{\beta}$ & $\mathbf{R}^{\mathbf{2}}$ & Adjusted $\mathbf{R}^{\mathbf{2}}$ & $\mathbf{t}$ & $\mathbf{p}$ \\
\hline 1.40 & 0.522 & 0.597 & 0.356 & 0.306 & 2.680 & $0.019^{*}$ \\
\hline
\end{tabular}

" $\mathrm{p}<0.05$ 
sis had greater effect from mirror therapy $(p<0.05)$, and prosthesis usage explained $30.6 \%$ of the change in average PLP scores before and after mirror therapy (Adjusted $R^{2}=0.306, p<0.05$ ) (Table 4).

There was no significant relationship between effect of mirror therapy and demographic, amputation or PLP-related characteristics of the patients $(p>0.05)$. No significant difference was found in correlation analysis between average PLP score before and after mirror therapy, the average number $(r s=0.178)$ and duration ( $r s=-0.315$ ) of mirror therapy sessions practiced for 4 weeks ( $p>0.05$ ).

\section{Discussion}

Mirror therapy has become a leading alternative for treatment of PLP in the last 2 decades, and many experimental studies have been done to learn more about this therapy. ${ }^{[13,14,26-30]}$ It is a method that can be used independently by nurses to manage the care of a patient with PLP. In addition, it provides a great opportunity for amputees to be able to manage their pain themselves. Therefore, the use of mirror therapy in the nursing care of patients with PLP should be researched and the results should be shared. The present study investigated the effect of mirror therapy on the management of PLP and evaluated the results from the perspective of clinical practice and nursing care.

In the present study, $80 \%$ of patients stated that they had a painful period before the amputation. As all the patients in this sample were experencing PLP, and most of them had significant pre-amputation pain, it may be said that PLP may be correlated with preamputation pain. This is confirmed in the literature. ${ }^{[10,15,23,31,32]}$

Patients in this sample practiced mirror therapy every day for 4 weeks at home or hospital with a mirror that was given to them. The therapy gave them the ability to control their phantom pain. In the study of Darnall (2009), a patient who practiced mirror therapy at home for 3 months stated that his ability to manage his phantom pain increased with mirror therapy. MacLachlan et al. (2004) reported that a patient who had not been able to control phantom limb movements stated that his level of control increased $25 \%-30 \%$ after 3 weeks of mirror therapy.
The number of studies investigating the direct effect of mirror therapy on PLP is limited and they have small samples. Chan et al. (2007) conducted an experimental study with 18 patients and compared the results of mirror therapy, closed mirror therapy and imagination of phantom movements. They reported that in all groups, the severity of PLP decreased; however, after 1 month, the decrease in the mirror therapy group was significantly higher. Afterwards, they asked the patients in the groups of closed mirror and imagination to practice mirror therapy for 1 month. At second month, the decrease in the severity of PLP in these groups were also significant. Foell et al. (2014) reported 27\% decrease in PLP of their sample of 13 patients that praticed mirror therapy for 4 weeks. In the study of Sumitani et al. (2008), the decrease in PLP was found to be sigfinicant and 11 patients out of 22 stated that their pain level had decreased 30\%-50\% after mirror therapy. These literature findings are parallel to the findings of the present study. In this study sample, the average pain score given by patients after mirror therapy decreased significantly each week $(p<0.01)$.

Fulfillment of mirror therapy on a regular basis is a key point in the success of this method. Among the studies in the literature, mirror therapy was practiced on regular basis and the duration of therapy sessions was $10-30$ minutes. ${ }^{[33,35-38]}$ In the case study of Darnal (2009), patient stated that when he stopped doing mirror therapy, PLP started again after 1-2 days. In this study, patients were asked to practice mirror therapy every day for at least 20 minutes. In the correlation analysis, there was no significant difference between the success of mirror therapy and the number of repetitions of practice per day and the duration of a single session. Therefore it can be said that to have beneficial outcomes, the important element is that mirror therapy be done on a regular basis; the number of repetitions and longer therapy sessions do not have any impact on success.

In this study, patients who were not using any prosthesis saw greater benefit from mirror therapy $(p<0.05)$. Only $33.3 \%(n=5)$ of the patients were using prosthesis and all were wearing cosmetic prosthesis. As cosmetic prostheses restrict limb and joint movements, it may be perceived in the brain as a paralyzed limb, and in direct proportion, may inhibit regression 
of cortical reorganization. There are certain findings which proove that mirror therapy decreases PLP by helping the regression of changed cortical map. ${ }^{[28-39]}$ Patients with cosmetic prostheses took off the prostheses only when practicing mirror therapy. For a large portion of the day, they were wearing the prosthesis, and thus, may be blocking possible positive effect of mirror therapy on their cortical brain map. On the other hand, certain literature findings state that myoelectrical prostheses which use existing muscles in the residual limb are helpful to decrease PLP. ${ }^{[40,41]}$ The fact that mirror therapy supports regression of cortical reorganization, and that a cosmetic prothesis may be perceived as a paralysed limb may explain greater decrease in PLP among patients who were not using a prosthesis.

Nevertheless, there were some limitations in the present study. The main limitation of mirror therapy practice is that it is only applicable for persons with unilateral limb loss. In addition, the patients in this study were asked to practice mirror therapy every day at least 20 minutes for 4 weeks. Some patients had difficulty continuing to practice or practicing on a regular basis. Therefore, the study sample was not big enough to do comparable statistical analysis. As the sample size was 15, it wasn't possible to evaluate the effect of demographic and amputation-related characteristics on the success of mirror therapy.

\section{Conclusions}

Although this study was conducted with a small sample, the results obtained were encouraging. Consequently, it can be said that mirror therapy is a helpful means of managing and decreasing PLP and helps patients have control over their pain. This method can also be easily practiced at home and is easy to teach as part of the nursing care of patients with PLP.

\section{Implications for nursing practice}

This is the first study addressing the importance of mirror theapy on the nursing care of a patient with PLP. According to the findings of this study, to improve the quality of nursing care of patients with PLP, it can be suggested that mirror therapy should be used widely in the holistic nursing care of amputees with PLP in collaboration with other disciplines such as anesthesiology, surgery, psychology, and psychiatry.

Since mirror therapy is a method that the nurse can teach and use independently, nurses in surgical units, in particular, should be aware of this method and their ability to independently decide to utilize this method should be supported by the healthcare team and management. Mirror therapy is a method that can be taught in a short time, and it should be added to the nursing care plan of a new amputee in case PLP is experienced before discharge from the hospital. Nurses can plan a group training session, and/or the repetitive practical sessions may also be done in groups, which may increase and help maintain patient motivation to continue mirror therapy.

In addition, it can be suggested that similar studies should be done with larger and more homogeneous samples in a controlled experimental study.

\section{Acknowledgements}

The authors would like to thank all the patients who participated in the study for their effort. In addition, special thanks to Professor Neriman Akyolcu, Professor Gül Köknel Talu and Associate Professor Beth Darnall for their support at every step of this thesis project. We would also like to thank to Assistant Professor Çiğdem Kaspar for her help with the statistical analysis of the data.

\section{Conflict-of-interest issues regarding the authorship or article: None declared.}

Peer-rewiew: Externally peer-reviewed.

\section{References}

1. Karl A, Birbaumer N, Lutzenberger W, Cohen LG, Flor H. Reorganization of motor and somatosensory cortex in upper extremity amputees with phantom limb pain. J Neurosci 2001;21(10):3609-18.

2. Hanley MA, Ehde DM, Campbell KM, Osborn B, Smith DG. Self-reported treatments used for lower-limb phantom pain: descriptive findings. Arch Phys Med Rehabil 2006;87(2):270-7.

3. Flor H. Maladaptive plasticity, memory for pain and phantom limb pain: review and suggestions for new therapies. Expert Rev Neurother 2008;8(5):809-18.

4. Casale $\mathrm{R}$, Alaa L, Mallick M, Ring $\mathrm{H}$. Phantom limb related phenomena and their rehabilitation after lower limb amputation. Eur J Phys Rehabil Med 2009;45(4):559-66.

5. Brodie EE, Whyte A, Niven CA. Analgesia through the looking-glass? A randomized controlled trial investigating the effect of viewing a 'virtual' limb upon phantom limb pain, sensation and movement. Eur J Pain 2007;11(4):428-36.

6. Ehde DM, Czerniecki JM, Smith DG, Campbell KM, Edwards WT, Jensen MP, et al. Chronic phantom sensations, 
phantom pain, residual limb pain, and other regional pain after lower limb amputation. Arch Phys Med Rehabil 2000;81(8):1039-44.

7. Behr J, Friedly J, Molton I, Morgenroth D, Jensen MP, Smith DG. Pain and pain-related interference in adults with lower-limb amputation: comparison of knee-disarticulation, transtibial, and transfemoral surgical sites. J Rehabil Res Dev 2009;46(7):963-72.

8. Gagné M, Reilly KT, Hétu S, Mercier C. Motor control over the phantom limb in above-elbow amputees and its relationship with phantom limb pain. Neuroscience 2009;162(1):78-86.

9. Kawashima N, Mita T. Metal bar prevents phantom limb motion: case study of an amputation patient who showed a profound change in the awareness of his phantom limb. Neurocase 2009;15(6):478-84.

10. Ramachandran VS, Hirstein W. The perception of phantom limbs. The D. O. Hebb lecture. Brain 1998;121(9):1603-30..

11. Anderson-Barnes VC, McAuliffe C, Swanberg KM, Tsao JW. Phantom limb pain--a phenomenon of proprioceptive memory? Med Hypotheses 2009;73(4):555-8.

12. Cole J, Crowle S, Austwick G, Slater DH. Exploratory findings with virtual reality for phantom limb pain; from stump motion to agency and analgesia. Disabil Rehabil 2009;31(10):846-54.

13. Ramachandran VS, Altschuler EL. The use of visual feedback, in particular mirror visual feedback, in restoring brain function. Brain 2009;132(Pt 7):1693-710.

14. Diers M, Christmann C, Koeppe C, Ruf M, Flor H. Mirrored, imagined and executed movements differentially activate sensorimotor cortex in amputees with and without phantom limb pain. Pain 2010;149(2):296-304.

15. Karanikolas M, Aretha D, Tsolakis I, Monantera G, Kiekkas P, Papadoulas $S$, et al. Optimized perioperative analgesia reduces chronic phantom limb pain intensity, prevalence, and frequency: a prospective, randomized, clinical trial. Anesthesiology 2011;114(5):1144-54.

16. Liu RJ, Fuchikami M, Dwyer JM, Lepack AE, Duman RS, Aghajanian GK. GSK-3 inhibition potentiates the synaptogenic and antidepressant-like effects of subthreshold doses of ketamine. Neuropsychopharmacology 2013;38(11):2268-77.

17. Manchikanti L, Singh V. Managing phantom pain. Pain Physician 2004;7(3):365-76.

18. Weeks SR, Anderson-Barnes VC, Tsao JW. Phantom limb pain: theories and therapies. Neurologist 2010;16(5):277-86.

19. Giummarra MJ, Gibson SJ, Georgiou-Karistianis N, Bradshaw $J$. Central mechanisms in phantom limb perception: the past, present and future. Brain Res Rev 2007;54(1):219-32.

20. Ketz AK. The experience of phantom limb pain in patients with combat-related traumatic amputations. Arch Phys Med Rehabil 2008;89(6):1127,32.

21. Ramachandran VS. Plasticity and functional recovery in neurology. Clin Med (Lond) 2005;5(4):368-73.

22. Ramachandran VS, McGeoch PD. Occurrence of phantom genitalia after gender reassignment surgery. Med Hypotheses 2007;69(5):10013.

23. Nikolajsen $\mathrm{L}$, Jensen TS. Phantom limb pain. Br J Anaesth 2001;87(1):107-16.

24. Ramachandran VS. Phantom limbs, neglect syndromes, repressed memories, and Freudian psychology. Int Rev Neu- robiol 1994;37:291-333; discussion 369-72.

25. Ramachandran VS, Rogers-Ramachandran D. Synaesthesia in phantom limbs induced with mirrors. Proc Biol Sci 1996;263(1369):377-86.

26. Chan BL, Witt R, Charrow AP, Magee A, Howard R, Pasquina $\mathrm{PF}$, et al. Mirror therapy for phantom limb pain. $\mathrm{N}$ Engl J Med 2007;357(21):2206-7.

27. Darnall BD. Self-delivered home-based mirror therapy for lower limb phantom pain. Am J Phys Med Rehabil 2009;88(1):78-81.

28. Hanling SR, Wallace SC, Hollenbeck KJ, Belnap BD, Tulis MR. Preamputation mirror therapy may prevent development of phantom limb pain: a case series. Anesth Analg 2010;110(2):611-4.

29. McCabe C. Mirror visual feedback therapy. A practical approach. J Hand Ther 2011;24(2):170-9.

30. Ramachandran VS, Blakeslee S. Phantoms in the Brain, Probing The Mysteries of the Human Mind. [Book in Turkish] Translated by: Levent Ozturk. Istanbul, Turkey: BU Press; 2011.

31. Houghton AD, Nicholls G, Houghton AL, Saadah E, McColl L. Phantom pain: natural history and association with rehabilitation. Ann R Coll Surg Engl 1994;76(1):22,5.

32. Borsje S, Bosmans JC, van der Schans CP, Geertzen JH, Dijkstra PU. Phantom pain: a sensitivity analysis. Disabil Rehabil 2004;26(14-15):905-10.

33. MacLachlan M, McDonald D, Waloch J. Mirror treatment of lower limb phantom pain: a case study. Disabil Rehabil 2004;26(14-15):901-4.

34. Foell J, Bekrater-Bodmann R, Diers M, Flor H. Mirror therapy for phantom limb pain: brain changes and the role of body representation. Eur J Pain 2014;18(5):729-39.

35. Sumitani M, Miyauchi S, McCabe CS, Shibata M, Maeda L, Saitoh Y, et al. Mirror visual feedback alleviates deafferentation pain, depending on qualitative aspects of the pain: a preliminary report. Rheumatology (Oxford) 2008;47(7):1038-43.

36. Anaforoglu B. The comparison of the effect of mirror therapy and phantom exercises in phantom pain treatment. [PhD dissertation]. Hacettepe University, Institute of Health Sciences, Prosthetics-Orthotics and Biomechanics Program, Ankara, Turkey; 2011.

37. Wilcher DG, Chernev I, Yan K. Combined mirror visual and auditory feedback therapy for upper limb phantom pain: a case report. J Med Case Rep 2011;5:41.

38. Kim SY, Kim YY. Mirror therapy for phantom limb pain. Korean J Pain 2012;25(4):272-4.

39. Imai I, Takeda K, Shiomi T, Taniguchi T, Kato H. Sensorimotor cortex activation during mirror therapy in healthy righthanded subjects: A study with near-infrared spectroscopy. J Phys Ther Sci 2008;20(2):141-5.

40. Dietrich C, Walter-Walsh K, Preissler S, Hofmann GO, Witte OW, Miltner WH, et al. Sensory feedback prosthesis reduces phantom limb pain: proof of a principle. Neurosci Lett 2012;507(2):97-100.

41. Ortiz-Catalan $M$, Sander N, Kristoffersen MB, Håkansson $B$, Brånemark R. Treatment of phantom limb pain (PLP) based on augmented reality and gaming controlled by myoelectric pattern recognition: a case study of a chronic PLP patient. Front Neurosci 2014;8:24. 